\title{
Mathematics Literacy: Newman's Error Analysis (NEA) Review from Habits of Mind
}

\author{
Rina Sari Lubis ${ }^{1, *}$ Ikrar Pramudya ${ }^{2}$ Sri Subanti ${ }^{3}$ \\ ${ }^{I}$ Magister of Mathematics Education, Faculty of Teacher Training and Education, Universitas Sebelas Maret \\ Surakarta, Indonesia \\ ${ }^{2,3}$ Faculty of Teacher Training and Education, Universitas Sebelas Maret Surakarta, Indonesia \\ *Corresponding author. Email: rinalubis@student.uns.ac.id
}

\begin{abstract}
This research aims to analyze and describe the mistakes made by students in solving mathematical literacy skills in terms of habits of mind. This study uses a qualitative research method by describing students' mistakes in solving mathematical literacy skills in terms of habits of mind limited, developing, and proficient, as well as the factors that cause errors. These errors were analyzed based on indicators of mathematical literacy ability and to find out the type of error based on Newman's errors. Data collection techniques used are questionnaires, tests, and interviews. The instrument used is a questionnaire of habits of mind and a test of mathematical literacy skills. The selection of research subjects was carried out purposively with several considerations, namely the subject had a habit of mind category which amounted to 5 subjects. The data analysis techniques used in this research are data reduction, data presentation, and conclusion drawing. Based on the results of the study, subjects with habits of mind limited were only able to solve questions up to level 1 because they made mistakes in process skills. Subjects with habits of mind developing, were only able to complete questions up to level 2 because they made a misunderstanding. While the other subjects were able to complete the questions up to level 4 because they made a reading error. Subjects with habits of mind proficient, were only able to complete the questions up to level 3 because they made a misunderstanding. While the other subjects were only able to solve the problem up to level 2 because they made a mistake on the level 3 question, the error made was an misunderstanding. Factors that cause errors made are haste, lack of thoroughness, error in processing skills, misunderstanding, not understanding the material, and reading errors.
\end{abstract}

Keywords: Analysis, Factors causing errors, Habits of mind, Mathematical literacy ability, Newman errors.

\section{INTRODUCTION}

Mathematics learning is very close to everyday life, so it is hoped that students can understand mathematics in various contexts and apply it in everyday life. Mathematical literacy skills are useful for helping students when solving math problems in their daily lives [1]. So, it is expected that students have good mathematical literacy skills, namely being able to formulate and interpret mathematics in various contexts [2].

The importance of mathematical literacy skills is not in line with what happens to students. Based on research on mathematical literacy skills conducted in Tasikmalaya, prospective mathematics teachers have poor mathematical literacy skills, because the research subjects have not been able to solve problems at levels 5 and 6 [3]. In addition, research on mathematical literacy skills conducted in Mataram showed that students still had difficulty working on high-level mathematical literacy skills, in this study, namely level 3 and level 4 [4]. The results of research conducted in the cities of Bandung, Medan, Yogyakarta, Palembang, Samarinda, Kendari, and Kupang on high school students and equivalent stated that students' mathematical literacy results were still low, even though the questions had been adapted to the Indonesian context [5].

When working on questions that require a complex level of thinking, students still find it difficult [6]. These difficulties resulted in students finally making mistakes in solving problems. So it is necessary to 
analyze so that it can be used by teachers as a basis for providing learning. Various errors made by students, according to Newman, there are 5 mistakes made by students, namely errors in reading questions, errors in understanding questions, transformation errors, errors in process skills and errors in writing the final answer [7].

The affective aspect also affects students when answering questions. In addition to cognitive aspects, affective aspects also need to be improved according to the 2013 curriculum. Students are expected to be able to improve cognitive, affective and psychomotor aspects [1]. Students must have one of the affective abilities, namely habits of mind or thinking habits [8]. Good habits of mind are very much needed for students (individuals) because habits of mind form a preference for individuals to behave intellectually or think intelligently when faced with a problem. Habits of mind need to be built by individuals from an early age so that it becomes a habit they have in solving a problem. But unfortunately, there are still many individuals or students who have less habits of mind so that it becomes an obstacle both in solving a problem in everyday life or when working on math problems. Habits of mind are still an obstacle for students to solve complex problems [9]. Mathematical literacy ability is divided into 6 levels where levels 1 and 2 are the level of questions with the lowest ratio (easy), levels 3 and 4 include level questions with a medium ratio (medium), while levels 5 and 6 are questions with a high ratio (complicated). [10]. The results of research conducted in several areas such as: Tasikmalaya, Bandung, Medan, Yogyakarta, Palembang, Samarinda, Kendari, Kupang, and Mataram as well as the PISA results of Indonesian students at the international level regarding mathematical literacy skills, and the importance of habits of mind in completing an assignment. math problem. Based on the literature review, there is still potential for research that focuses on the description of students' errors in solving mathematical literacy problems on different habits of mind.

This study aims to describe errors and factors that cause students to make mistakes in solving mathematical literacy skills in terms of habits of mind. Students' mistakes need to be explored based on habits of mind so that students have intelligent responses to questions or problems whose solutions are not immediately known.

\section{METHODS}

\subsection{Design}

This research, the method used is descriptive qualitative which aims to describe/explain the mistakes made by students when working on mathematical literacy skills. Descriptive research is research by providing an overview of the presentation of reports in the form of words, pictures and not numbers that is carried out to understand phenomena that occur in research subjects such as actions, behavior, perceptions, motivations or other things holistically by describing in words and language, in a natural context by utilizing various scientific methods [11].

\subsection{Participants}

This research will focus on the eighth-grade students of MTsN 4 South Tapanuli. Research subjects were taken using purposive sampling. Purposive Sampling is a sampling technique of data sources with certain considerations [12]. This research, the considerations are that the subject has the categories of habits of mind limited, developing, and proficient; students make mistakes when working on mathematical literacy ability test questions; students can express opinions; and these students are willing to be research subjects. Subjects are expected to provide maximum information.

Table 1. The result of the validation

\begin{tabular}{|c|c|}
\hline Validator & Validation \\
\hline Validator 1 & $\begin{array}{l}\text { Criticism and suggestions } \\
\text { Correct the sentences in the questions to be more communicative, using good and correct } \\
\text { Indonesian } \\
\text { General rating } \\
\text { Questions can be used, but need to be revised a little }\end{array}$ \\
\hline Validator 2 & $\begin{array}{l}\text { Criticism and suggestions } \\
\text { Improve word choice in translating questions } \\
\text { General rating } \\
\text { The test can be used with revision }\end{array}$ \\
\hline
\end{tabular}




\subsection{Instruments}

The type of instrument used is test and non-test. The test instrument used is a mathematical literacy test adapted from PISA. Meanwhile, the non-test instruments used were questionnaires and interviews. The question instrument was validated by two validators, namely a lecturer in mathematics education at Institut Agama Islam Negeri Padangsidimpuan. The results of the validation by the validator can be seen in the following Table 1 .

The questionnaire in this research was intended to obtain information about the habits of mind of students who would be analyzed into the habits of mind category, namely: novice, limited, developing, proficient, and distinguished. The instrument for classifying the habits of mind of students uses a modified habits of mind questionnaire from Hendriana (2017) by paying attention to the habits of mind indicator based on Costa \& Kallick. The answer choices are sorted from the most negative to the most positive based on the stages of the habits of mind category. If most of the students choose the most negative answer, it means that the student has habits of mind for beginners, as well as the other answer choices. The questionnaire grid can be seen in the following Table 2 .

Table 2. The questionnaire grids

\begin{tabular}{|l|c|c|}
\multicolumn{1}{|c|}{ Indicator } & \multicolumn{2}{c|}{ Statement } \\
\cline { 2 - 3 } & Positif (+) & Negatif (-) \\
\hline Never give up & 1,2 & 3,4 \\
\hline Regulate conscience, think reflectively, solve problems carefully & 5,6 & 7,8 \\
\hline Listening to the opinions of others with understanding and empathy & 9,10 & 11,12 \\
\hline Think flexibly, confidently & 13,14 & 15,16 \\
\hline Thinking about thinking/metacognitive & 17,18 & 19,20 \\
\hline Try to work carefully and precisely & 21,22 & 23,24 \\
\hline Ask and raise problems effectively & 25,26 & 27,28 \\
\hline Applying old knowledge to new situations & 29,30 & 31,32 \\
\hline Think and communicate clearly and thoroughly & 33,34 & 35,36 \\
\hline Gather and use all senses, think intuitively, and make approximate solutions & 37,38 & 39,40 \\
\hline Creating, imagining, and innovating & 41,42 & 43,44 \\
\hline Eager to respond & 45,46 & 47,48 \\
\hline Dare to take responsibility and take risks & 49,50 & 51,52 \\
\hline Humorous & 53,54 & 55,56 \\
\hline Thinking interdependent & 57,58 & 59,60 \\
\hline Continuous learning & 61,62 & 63,64 \\
\hline
\end{tabular}

\subsection{Data Collection Method}

The data collection techniques used in this research were tests of mathematical literacy skills, questionnaires, and interviews. The subject filled out the habits of mind questionnaire which was then analyzed for the habits of mind category owned by each student, as well as the errors made by the subject in working on the mathematical literacy ability test questions and the factors that caused these errors.

\subsection{Data Analysis}

The data analysis stage is reduction, presentation, and conclusion drawing. Data reduction means summarizing, choosing the main things, focusing on the important things and looking for patterns [12]. After being reduced, the presentation of data in qualitative research can be done in the form of brief descriptions, charts, relationships, flowcharts and the like. Conclusions are drawn by analyzing the results of tests and interviews with students (subjects). The conclusion of this study is the result of an analysis of students' errors in solving mathematical literacy skills and also the causes of these errors.

\section{RESULT}

This research was conducted on students at MTsN 4 Tapanuli Selatan, by setting class VIII-7 as the class for taking research subjects based on several considerations. The research conducted in the field includes the activities of distributing habits of mind questionnaires and filling out mathematical literacy ability test questions. Questionnaires were distributed to 29 students of class VIII-7 who were present at the time.

The distribution of the questionnaire was carried out on the subject of one class with the aim of knowing how the tendencies of students were from the 
indicators of the habits of mind of students. The questionnaire that has been filled out by the subject is then reduced by considering positive answers for positive statements and negative for negative statements based on the habits of mind stages, so that the habits of mind category are obtained from each student. Furthermore, after filling out the habits of mind questionnaire to the students, the researchers carried out a mathematical literacy test and interviews.

\subsection{Research results on Subject 1 (S1)}

Subjects with habits of mind in the limited category are S1. From the results of the work on the mathematical literacy ability test in Figure 1, S1 can solve question number 1 correctly and fulfill all indicators of level 1 mathematical literacy ability. In question number 2, S1 made an error which was a level 2 question of mathematical literacy ability. S1 is only able to answer 2 of the 4 indicators at level 2, namely interpreting and recognizing situations with contexts that require direct conclusions and sorting out relevant information from a single source and using a single presentation method. In the indicators of working on the basic algorithm, using formulas and carrying out simple procedures, S1 has difficulty when working on the basic algorithm, namely in the division process, causing errors to occur.

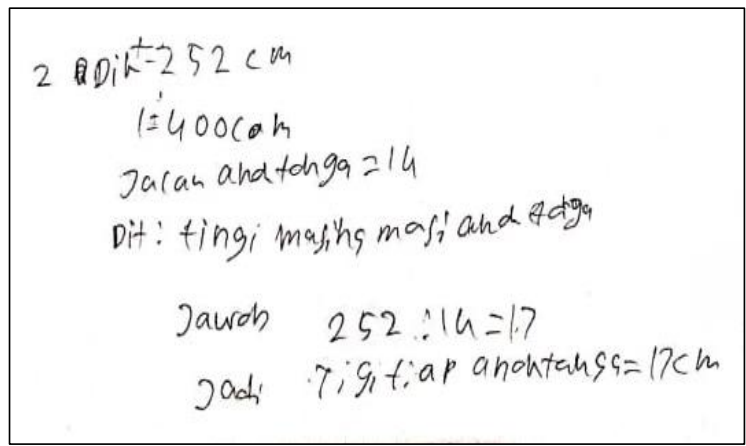

Figure 1 Answer by S1 number 2

When working on the questions, S1 shows several indicators of habits of mind including a lack of confidence which can be seen when S1 is hesitant in answering and a lack of trying to work carefully and precisely which can be seen in question number 2 , and indicators of never giving up which are minimal because at when doing division and having difficulty $\mathrm{S} 1$ tends to guess the answer.

\subsection{Research results on Subject 2 (S2)}

S2 is a subject with the category of developing habits of mind (developing). In question number 1 based on the results of work (Figure 2) and interviews with S2, S2 was able to work on the questions correctly according to level 1 indicators. S2 was also able to work on level 2 questions, S2 had difficulties when doing the division but he was able to solve it. Overall S2 can meet all the indicators on the level 2 question. In question number 3, S2 made an error which is a matter of level 3 mathematical literacy ability. S2 is only able to answer 2 of the 4 indicators in question number 3 , namely carrying out procedures clearly, including procedures that require sequential decisions and can solve problems, and apply simple strategies. As can be seen in the answer sheet number 3a. However, Masters cannot fulfill the indicators of interpreting and using representations based on different sources of information and stating the reasons directly and communicating the results of their interpretations and reasons. Where S2 cannot understand the information given in question number $3 \mathrm{~b}$, so the answer does not meet the indicators at level 3.

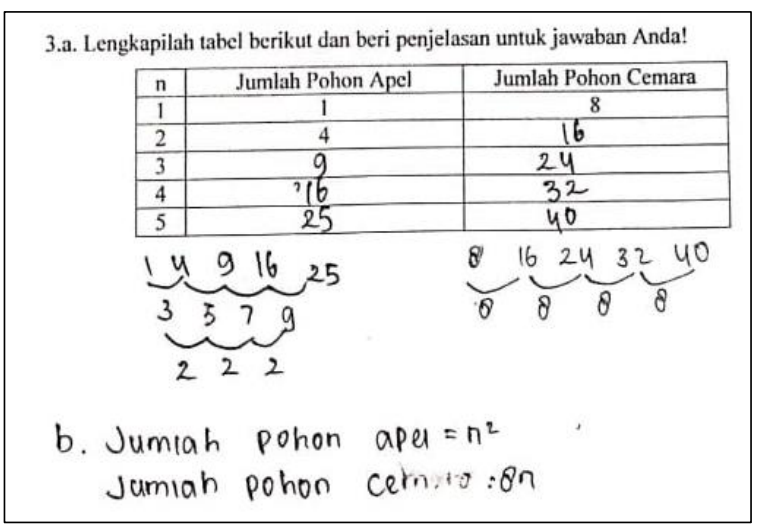

Figure 2 Answer by S2 number 3

When working on the questions, $\mathrm{S} 2$ shows several indicators of habits of mind including lack of confidence which can be seen when S2 is hesitant in answering and the lack of indicators of never giving up because Master gives up when working on question number $3 b$ where he has not finished working on it. Based on the results of tests and interviews, it can be seen that the factors causing S2 to make mistakes are lack of thoroughness and misunderstanding. 


\subsection{Research results on Subject 3 (S3)}

S3 is a subject with the category of developing habits of mind. In question number 1 based on the results of the work and interview S3 is able to work on the questions correctly according to level 1 indicators. On question number $2 \mathrm{~S} 3$ is able to work on questions correctly according to level 2 indicators. correct according to the indicator even though it must be clarified during the interview. At number 4, S3 can also complete correctly according to level 4 indicators. In question number 5 (Figure 3), S3 makes an error which is a matter of level 5 mathematical literacy ability. S3 is not able to meet all the indicators on level 5 questions, namely: developing and working with models for complex situations, identifying problems, and setting assumptions; select, compare, and evaluate appropriately problem solving strategies related to complex problems related to the model; work strategically using broad thinking and reasoning, as well as appropriately linking symbolic representations and formal characteristics and knowledge related to situations; and reflect on their work and be able to formulate and communicate their interpretations and reasons.

$$
\begin{aligned}
& 5 \text { diketa: } 12 \text { /defik } \\
& \text { datanyakan- Berapa kar ty yang diperlakan }
\end{aligned}
$$

Figure 3 Answer by S3 number 5

When working on the questions, S3 shows an indicator of habits of mind, namely the lack of an indicator of never giving up because S3 does not continue to work on question number 5 until it is finished. Based on the results of tests and interviews, it can be seen that the factors causing S3 to make mistakes are not understanding the material and reading errors.

\subsection{Research results on Subject 4 (S4)}

S4 is a subject with the category of proficient habits of mind. S4 was able to solve the problem correctly up to number 3 , because $\mathrm{S} 4$ made an error in question number 4. In question number 4 (Figure 4) S4 seemed confident of the answer he got, because he smoothly wrote his answer on the answer sheet. However, after the interview, it can be seen that he cannot meet the indicators at level 4 , namely selecting and combining different representations, connecting them to real situations; use their limited range of skills and present reasons with multiple views in a clear context; provide explanations and communicate them with arguments based on their interpretations and actions. Because S4 cannot meet the 3 indicators on level 4 questions, it causes S4 does not meet level 4 mathematical literacy skills, where the error made is an understanding error.

$$
\begin{aligned}
& \text { 4. Dik = selama } 3 \text { bln nilai tukar berubah "u2 menjudi } 4 ; 02 A R \\
& D_{\mid t}=\text { Apakah menguntungkan Mel-ling menukar sckarang, } \\
& \text { kerika diu menukarkan rand Aprikn selatan kembali } \\
& \text { ke dolar singapura? berikan peyjebsan } \\
& \text { Jawab: } 3000 \text { dolar singapura } \\
& =3.000 \times 4.0 \text { jika }=3.000 \times 4.2 \\
& =12000 \quad=12600 \\
& \text { Jadi jika mei-ling menukar sekarang akan rugi }
\end{aligned}
$$

Figure 4 Answer by S4 number 4

When working on questions, S4 shows several indicators of habits of mind, including high selfconfidence because when working on S4 questions they tend to be enthusiastic and work with confidence. In addition, the indicator of never giving up is also seen because he is very enthusiastic when working on questions. In addition, S4 also has an indicator of habits of mind trying to work carefully and precisely well. it can be seen that he is able to work on level 1 to level 3 questions correctly but is less thorough in understanding the questions on level 4 questions.

\subsection{Research results on Subject 5 (S5)}

S5 is a subject with the category of proficient habits of mind. In question number 1 based on the results of work and interviews with S5, S5 was able to do the questions correctly according to level 1 indicators. S5 was able to give the right reasons. Overall S5 can meet all indicators on level 2 questions.

In question number 3 (Figure 5), S5 made an error which was a level 3 question of mathematical literacy ability. S5 is only able to answer 2 of the 4 indicators in question number 3 , namely carrying out procedures clearly, including procedures that require sequential decisions and can solve problems, and apply simple strategies. As can be seen in the answer sheet number 3a. However, S5 cannot fulfill the indicators of interpreting and using representations based on different sources of information and stating the reasons directly and communicating the results of their interpretations and reasons. Where S5 cannot understand the information given in question number 
$3 b$, so the answer does not meet the indicators at level 3.

3.a. Lengkapilah tabel berikut dan beri penjelasan untuk jawaban Anda!
\begin{tabular}{|c|c|c|}
\hline $\mathrm{n}$ & Jumlah Pohon Apel & Jumlah Pohon Cemara \\
\hline 1 & 1 & 8 \\
\hline 2 & 4 & 16 \\
\hline 3 & 9 & 24 \\
\hline 4 & 16 & 32 \\
\hline 5 & 25 & 40 \\
\hline
\end{tabular}

Figure 5 Answer by S5 number 3

When working on the questions, S5 showed several indicators of habits of mind, namely the lack of indicators of never giving up because S5 gave up when working on question number $3 \mathrm{~b}$. Based on the results of tests and interviews, it can be seen that the factor that caused S5 to make mistakes was a misunderstanding.

The research that has been done discusses how students' mistakes in solving mathematical literacy skills are reviewed from the habits of mind category. Of the 5 categories mentioned by Costa and Kallick, this discussion will only discuss 3 categories found in the field, namely the limited category, the developing category, and the proficient category. Errors made by students on the mathematical literacy test were analyzed by taking into account the indicators of mathematical literacy ability at each level. The researcher also reveals the causes of errors based on Newman's theory which includes 5 types of errors, namely: reading, understanding, transformation, process skills, and final writing.

Subjects with habits of mind in the limited category are S1. From the results of the work on the mathematical literacy ability test, S1 can solve question number 1 correctly and fulfill all indicators of level 1 mathematical literacy ability. In question number $1 \mathrm{~S} 1$ answered the question correctly, it just took a long time to understand the question. In question number $2 \mathrm{~S} 1$ made a mistake, S1 was only able to answer 2 of the 4 indicators at level 2, namely interpreting and recognizing situations with contexts that require direct conclusions and sorting out relevant information from a single source and using a single presentation method. S1 does not seem to understand the arithmetic division operation and rarely performs calculations, causing the error to occur. The error that S1 made was a process skill error. Based on the results of the interview, $\mathrm{S} 1$ is also not used to calculating so it is slow when doing calculations. Some of these factors caused S1 to be in a hurry in answering and not checking the answers again. When working on the S1 questions, it shows several indicators of habits of mind including lack of confidence, hesitation in answering and lack of trying to work carefully and precisely which can be seen in question number 2, and the indicator of never giving up is minimal because when doing the division and experiencing S1 difficulty tends to guess the answer. Based on this, it can be stated that $\mathrm{S} 1$ experienced an error in process skills in question number 2 and the factors causing the error were haste, lack of accuracy, and process skill errors.

S2 is a subject with the category of developing habits of mind (developing). In question number 1 based on the results of work and interviews with S2, S2 was able to work on the questions correctly according to level 1 indicators. S2 was also able to work on level 2 questions, S2 had difficulties when doing the division but he was able to solve it. In question number 3, S2 made an error which is a level 3 question of mathematical literacy ability. S2 is only able to answer 2 of the 4 indicators in question number 3 , namely carrying out procedures clearly, including procedures that require sequential decisions and can solve problems, and apply simple strategies. However, Masters cannot fulfill the indicators of interpreting and using representations based on different sources of information and stating the reasons directly and communicating the results of their interpretations and reasons. When working on the S2 questions, some indicators of habits of mind show including lack of confidence, hesitation in answering and the lack of indicators of never giving up because Master gave up when working on question number $3 \mathrm{~b}$ where he had not finished working on it. Based on the results of tests and interviews, it can be seen that the factors causing S2 to make mistakes are lack of thoroughness and misunderstanding.

S3 is a subject with the category of developing habits of mind. On questions number 1 to number 4 based on the results of work and doctoral interviews, they are able to work on questions correctly according to level indicators. In question number 5, S3 was not able to fulfill all the indicators on level 5 questions, namely: developing and working with models for complex situations, identifying problems, and setting assumptions; select, compare, and evaluate appropriately problem solving strategies related to complex problems related to the model; work strategically using broad thinking and reasoning, as well as appropriately linking symbolic representations and formal characteristics and knowledge related to situations; and reflect on their work and be able to formulate and communicate their interpretations and 
reasons. Because S3 cannot identify the information contained in the questions so that they cannot continue to answer the questions. From the explanation above, it can be seen that $\mathrm{S} 3$ made a reading error, causing an error in number 5. When working on the S3 question, it showed an indicator of habits of mind, namely the lack of an indicator of never giving up because S3 did not continue working on question number 5 until it was finished. Based on the results of tests and interviews, it can be seen that the factors causing S3 to make mistakes are not understanding the material and reading errors.

$\mathrm{S} 4$ is a subject with the category of proficient habits of mind. $\mathrm{S} 4$ was able to solve the problem correctly up to number 3 , because $\mathrm{S} 4$ made an error in question number 4 . In question number $3 \mathrm{~S} 4$ was able to carry out procedures clearly, solve problems and apply the strategies that S4 arranged appropriately. S4 initially did not write down the method from which he got the answer because he already understood it as seen from the way he expressed his answer and when the researcher directed him to write the answer, he was a little confused but was able to write down what was on his mind on the answer sheet. However, after the interview, it can be seen that he cannot meet the indicators at level 4, namely selecting and combining different representations, connecting them to real situations; use their limited range of skills and present reasons with multiple views in a clear context; provide explanations and communicate them with arguments based on their interpretations and actions. Because S4 cannot meet the 3 indicators on level 4 questions, it causes S4 does not meet level 4 mathematical literacy skills, where the error made is an understanding error. However, there is a uniqueness or finding in S4, namely that he made a mistake on the level 4 question but was able to answer correctly on the level 6 question. This is not in accordance with the theory because the higher the level of mathematical literacy ability, the more difficult the question will be. This also only occurred in S4, which was not found in the other subjects.

When working on S4 questions, it shows several indicators of habits of mind including high selfconfidence because when working on S4 questions they tend to be enthusiastic and work with confidence. In addition, S4 also has an indicator of habits of mind trying to work carefully and precisely well. it can be seen that he is able to work on level 1 to level 3 questions correctly but is less thorough in understanding the questions on level 4 questions, and misunderstanding.
S5 is a subject with the category of proficient habits of mind. In questions number 1 and number 2 based on the results of work and interviews with S5, S5 was able to do the questions correctly according to level 1 and level 2 indicators. In question number 3, S5 was only able to answer 2 of the 4 indicators in question number 3 , namely carrying out the procedure clearly, including procedures that require sequential and problem-solving decisions, and apply simple strategies. As can be seen in the answer sheet number 3a. However, S5 cannot fulfill the indicators of interpreting and using representations based on different sources of information and stating the reasons directly and communicating the results of their interpretations and reasons. Where S5 cannot understand the information given in question number $3 \mathrm{~b}$, so the answer does not meet the indicators at level 3. From the explanation above, it can be seen that S5 made a misunderstanding, causing an error in number 3b. When working on the S5 questions, it shows several indicators of habits of mind, namely the lack of indicators of never giving up because S5 gave up when working on question number $3 \mathrm{~b}$. Based on the results of tests and interviews, it can be seen that the factor that caused S5 to make mistakes was a misunderstanding.

Based on the results of the mathematical literacy test which contained 6 questions given to 5 subjects, the results showed different results. S1 with limited habits of mind is only able to reach level 1 while at level 2 he has not managed to answer the questions correctly. Master's degree with habits of mind development (developing) was able to reach level 2, but did not succeed in answering question number 3 correctly. S3 with habits of mind development (developing) was able to reach level 4, but made an error at level 5. S4 with habits of mind was proficient (proficient) was able to reach level 3, but made an error at level 4. And S5 with habits of mind was proficient (proficient), able to reach level 2, but made mistakes on level 3 questions. This is in line with the results of Widodo's research (2015), that students' mathematical literacy skills are still relatively low because errors are still found in student work, especially at high levels.

\section{CONCLUSION}

Based on the discussion that has been carried out by researchers on 3 research subjects, the following conclusions are obtained: 
1. Students' errors in solving mathematical literacy skills are as follows:

a. Subjects with limited habits of mind category are only able to solve questions up to level 1 because they make mistakes on level 2 questions. the solution. In this level 2 question, the subject made a process skill error.

b. Subjects with the category of developing habits of mind were only able to solve questions up to level 2, because they made mistakes on level 3 questions. Subjects could not fulfill the indicators of interpreting \& using representations based on different sources of information and stating reasons directly; unable to communicate the results of their interpretations and reasons. In this level 3 question, the subject made a misunderstanding. While the other subjects were only able to solve the questions up to level 4 , because they made mistakes on the level 5 questions. Subjects could not fulfill all indicators of level 5 mathematical literacy skills.

c. Subjects with the category of proficient habits of mind are only able to solve questions up to level 3, because they made an error in level 4 questions. Subjects cannot fulfill the indicators of choosing and combining different representations, including symbols, connecting them to real situations; use their limited range of skills and present reasons with multiple views in a clear context; provide explanations and communicate them with arguments based on their interpretations and actions. In this level 4 question, the subject made a misunderstanding. While the other subjects were only able to solve the questions up to level 2 , because they made mistakes on the level 3 questions. unable to communicate the results of their interpretations and reasons. In this level 3 question, the subject made a misunderstanding

2. Factors that cause errors in the subject of the limited habits of mind category are haste, inaccuracy, and process skill errors. Factors that cause errors in the category of developing habits of mind subjects are lack of thoroughness and misunderstanding. While on the other subject is not understanding the material and reading errors. Factors causing errors in the category of proficient habits of mind subjects are haste and misunderstanding. While on the other subject is a misunderstanding.

\section{REFERENCES}

[1] Purwasih, R., Sari, N. R., \& Agustina, S. (2018). Analisis Kemampuan Literasi Matematik dan Mathematical Habits of Mind Siswa SMP pada
Materi Bangun Ruang Sisi Datar. Jurnal Numeracy, 5(1), 67-76. Retrieved from http://numeracy.stkipgetsempena.ac.id/home

[2] Hasanah, U., Wardono, \& Kartono. (2016). Keefektifan Pembelajaran Murder Berpendekatan PMRI dengan Asesmen Kinerja pada Pencapaian Kemampuan Literasi Matematika Siswa SMP Serupa PISA. Unnes Journal of Mathematics Education, 5(2), 101108. Retrieved from http://journal.unnes.ac.id/sju/index.php/ujme

[3] Prabawati, M. N. (2018). Analisis Kemampuan Literasi Matematik Mahasiswa Calon Guru Matematika. Jurnal Mosharafa, 7(1), 113-120.

[4] Syawahid, M., \& Putrawangsa, S. (2017). Kemampuan Literasi Matematika Siswa SMP ditinjau dari Gaya Belajar. Jurnal Tadris Matematika, 10(2), 222-240.

[5] Mahdiansyah, \& Rahmawati. (2014). Literasi Matematika Siswa Pendidikan Menengah: Analisis Menggunakan Desain Tes Internasional dengan Konteks Indonesia. Jurnal Pendidikan dan Kebudayaan. 20(4), 452-469. Retrieved from http://jurnaldikbud.kemdikbud.go.id/index.php/j pnk

[6] Mahmudah, W. (2018). Analisis Kesalahan Siswa dalam Menyelesaikan Soal Matematika Bertipe Hots Berdasar Teori Newman. Jurnal UJMC, 4(1), 49-56. Retrieved from http://ejurnal.unisda.ac.id/index.php/ujmc

[7] Karnasih, I. (2015). Analisis Kesalahan Newman Pada Soal Cerita Matematis (Newman's Error Analysis in Mathematical Word Problems). Paradikma, 8(1), 37-51. Retrieved from http://digilib.unimed.ac.id/1368/2/Full\%20Text. pdf

[8] Nuurjannah, P.E.I., Hendriana, H., \& Fitrianna, A. Y. (2018). Faktor Mathematical Habits Of Mind dan Kemampuan Literasi Matematis Siswa SMP di Kabupaten Bandung Barat. Jurnal Mercumatika : Jurnal Penelitian Matematika Dan Pendidikan Matematika, 2(2), 51-58. Retrieved from http://ejurnal.mercubuanayogya.ac.id/index.php/mercumatika

[9] Indriani, L. F., Yuliani, A., \& Sugandi, A. I. (2018). Analisis Kemampuan Penalaran Matematis dan Habits Of Mind Siswa SMP 
Dalam Materi Segiempat Dan Segitiga. Jurnal Math Educator Nusantara: Wahana Publikasi Karya Tulis Ilmiah Di Bidang Pendidikan Matematika, 4(2), 87-94. Retrieved from https://doi.org/10.29407/jmen.v4i2.11999

[10] Jufri, L. H. (2015). Penerapan Double Loop Problem Solving Untuk Meningkatkan Kemampuan Literasi Matematis Level 3 Pada Siswa Kelas VIII SMPN 27 Bandung. Jurnal Lemma: Prodi Pend Matematika STKIP PGRI SUMBAR, 2(1), 52-62.

[11] Moleong, L. J. (2016). Metodologi Penelitian Kualitatif. Bandung, Indonesia: PT Remaja Rosdakarya

[12] Sugiyono. (2016). Metode Penelitian Kuantitatif, Kualitatif, dan R\&D. Bandung: Alfabeta. 